\title{
mRNA expression profiles for Escherichia coli ingested by normal and phagocyte oxidase-deficient human neutrophils
}

\author{
Benjamin J. Staudinger, Michele A. Oberdoerster, Patrick J. Lewis, and Henry Rosen
}

Department of Medicine, University of Washington, Seattle, Washington, USA

To gain a better understanding of bacterial responses to complex and hostile environments generated within the neutrophil phagosome, we estimated mRNA abundance, using genomic arrays, in Escherichia coli cells ingested by normal and phagocyte oxidase-deficient human neutrophils. Genes regulated by the oxidant sensing transcription factor OxyR were among those strongly induced upon phagocytosis by normal, but not oxidase-deficient, neutrophils. Several genes related to nitrogen metabolism, especially those regulated by the $\mathrm{NtrC}$ and $\mathrm{NAC}$ proteins and transcribed via the $\sigma^{54}$ alternative sigma factor, were suppressed by both normal and oxidase-deficient neutrophils. A $\triangle o x y R S$ mutant strain of $E$. coli was significantly more susceptible than the parent strain to neutrophil-mediated killing, which suggests that OxyR-regulated gene products contribute a measure of resistance to neutrophil antimicrobial systems. The hypersusceptibility of the $\triangle o x y R S$ mutant was attenuated when oxidase-deficient neutrophils were employed, suggesting that much of the protection afforded by the OxyR regulon is against oxidative antimicrobial factors. Expression profiling of phagocytosed bacteria appears to provide useful information about conditions in the phagocytic vacuole and about bacterial defenses mounted in response to this hostile environment.

J. Clin. Invest. 110:1151-1163 (2002). doi:10.1172/JCI200215268.

\section{Introduction}

Individuals with defective neutrophil function or inadequate neutrophil numbers are hypersusceptible to serious infections with bacteria and fungi, supporting the view that neutrophils contribute significantly to host defense against these pathogens. Neutrophils ingest and kill microbes by enveloping them in a complex compartment, the phagosome, where typically microbes die in minutes to hours. Characterization of the intraphagosomal environment has proved challenging because of its dynamic nature and relative inaccessibility to analysis. The introduction of DNA arrays to examine whole genome expression profiles offers a novel approach to the analysis of phagocyte stresses on bacteria.

Genomic arrays permit efficient analysis of the transcriptional abundance of a large number of genes in a compact number of experiments. Bacteria appear to adapt to environmental changes, in part, by rapidly

Received for publication February 13, 2002, and accepted in revised form July 23, 2002.

Address correspondence to: Henry Rosen, Box 356420, Department of Medicine, University of Washington, Seattle, Washington 98195, USA. Phone: (206) 543-3238;

Fax: (206) 543-3947; E-mail: hqr@u.washington.edu.

Conflict of interest: No conflict of interest has been declared.

Nonstandard abbreviations used: chronic granulomatous disease (CGD); polymorphonuclear neutrophils (PMNs); diethylpyrocarbonate (DEPC); open reading frames (ORFs); HEPES-supplemented HBSS (HHBSS); kanamycin resistance determinant $\left(\mathrm{kan}^{\mathrm{R}}\right)$; ATP-binding cassette (ABC). adjusting patterns of DNA transcription. Since halflives of mRNAs range from 0.5 to 15 minutes (1), mRNA expression profiles from ingested bacteria can logically be used to draw inferences about conditions in the phagocytic vacuole. Such information might also identify metabolic pathways important for bacterial survival in phagocytic cells.

Pursuing this concept, we compared mRNA expression profiles of a uropathogenic, serum-resistant strain of Escherichia coli exposed to neutrophils under efficient and poorly opsonic conditions. At intervals, RNA was isolated and CDNA was hybridized to commercial genome arrays representing 4,290 open reading frames (ORFs) from E. coli K12, strain MG1655. The ratio of normalized hybridization signals to each ORF DNA was taken to reflect the relative abundance of the corresponding transcripts under the compared conditions.

Substantial changes in transcript abundance were observed for 77 genes. The most pronounced increases were found among a subset of genes regulated by the oxidant-sensing (hydrogen peroxide) OxyR transcription factor. When cells deficient in phagocyte oxidase function (chronic granulomatous disease, or CGD) were substituted for normal polymorphonuclear neutrophils (PMNs), the OxyR responses were not observed. The most pronounced decreases in transcript abundance were observed among genes related to the metabolism of nitrogenous compounds. Genes regulated by the $\mathrm{NtrC}$ transcription factor were especially prominent in this regard. 


\section{Methods}

Reagents and buffers. Water for critical reagent and buffer preparation was purchased (United States Pharmacopoeia sterile for irrigation, nonpyrogenic; Baxter Healthcare Corp., Deerfield, Illinois, USA). HEPES-supplemented HBSS (HHBSS) consisted of Hanks balanced salts without $\mathrm{Ca}, \mathrm{Mg}$, bicarbonate, or phenol red (N-2387; SigmaAldrich, St. Louis, USA), supplemented with $20 \mathrm{mM}$ HEPES, and adjusted with $\mathrm{NaOH}$ to $\mathrm{pH}$ 7.45. Lysisdenaturation buffer was prepared by combining $13.3 \mathrm{~g}$ guanidine isothiocyanate, $300 \mu \mathrm{l} 0.5 \mathrm{M}$ EDTA, pH 8.0, $750 \mu \mathrm{l} 10 \% \mathrm{SDS}, 1.5 \mathrm{ml} 2 \mathrm{M}$ sodium acetate, $\mathrm{pH} 4.0,2 \mathrm{ml}$ water, and $15 \mathrm{ml}$ acid citrate-saturated ( $\mathrm{pH} 4.3$ ) phenol (P-4682; Sigma-Aldrich) to give a final volume of $30 \mathrm{ml}$ (adapted from a recipe provided by S. Mosely, University of Washington). This solution was stored at room temperature and was supplemented on the day of use with $7.2 \mu \mathrm{l} / \mathrm{ml}$ of 2 -mercaptoethanol. Where indicated, buffer solutions were RNAse inactivated by room temperature incubation with $0.1 \%$ diethylpyrocarbonate (DEPC) followed by autoclaving to decompose residual DEPC. E. coli-specific primers (C5603; Sigma-Aldrich) containing reverse primers for 4,290 predicted ORFs of the E. coli MG1655 genome were dissolved in $42 \mu \mathrm{l}$ bottled water and stored at $-20^{\circ} \mathrm{C}$. Bacterial strains were maintained as frozen stocks (at $-80^{\circ} \mathrm{C}$ ) of glycerolized Luria-Bertani broth cultures (2). Periodically, scrapings of frozen cultures were streaked onto nutrient agar plates, grown overnight at $37^{\circ} \mathrm{C}$, and stored for up to 1 month at $4^{\circ} \mathrm{C}$. Single bacterial colonies were inoculated into $10 \mathrm{ml}$ trypticase soy broth, or, where indicated, Mueller-Hinton broth, and incubated at $37^{\circ} \mathrm{C}$ overnight with end-over-end tumbling. Bacterial cells were pelleted for 15 minutes at 3,400 $\mathrm{g}$ and washed once or twice in $0.1 \mathrm{M}$ sodium sulfate. Washed bacteria were suspended to the required turbidity at $540 \mathrm{~nm}$ in HHBSS, placed on ice, and used within 30 minutes of preparation. Human neutrophils were prepared from EDTA anticoagulated venous blood as described previously (3) and suspended in cold HHBSS at $10^{8}$ cells $/ \mathrm{ml}$. Blood donors with cytochrome $b$-positive, X-linked CDG (X' CGD) (4-6) have been described previously. Fresh autologous serum was maintained on ice until use. Serum was complement inactivated by heating for 30 minutes at $56^{\circ} \mathrm{C}$ and then maintained on ice until use.

Bacterial strains and plasmids. The principal E. coli strain used in this study was ATCC 11775 (American Type Culture Collection, Rockville, Maryland, USA), a human urinary isolate with surface phenotype O1:K1:H7, phylogenetic group B (typing courtesy of J. Johnson, University of Minnesota, Minneapolis, Minnesota, USA). The strain is serum resistant but readily susceptible to killing by nonoxidative neutrophil antimicrobial systems (7). Strain GS047 (MC4100 $\Delta$ oxyRS, obtained from G. Storz, NIH, Bethesda, Maryland, USA) $(8,9)$, has a kanamycin resistance determinant $\left(\operatorname{kan}^{\mathrm{R}}\right)$ from $\mathrm{Tn} 903$ in place of the BamHI-MscI chromosomal region encoding oxyR and oxyS. EC178 was constructed by P1 transduction of $\mathrm{kan}^{\mathrm{R}}$ into ATCC 11775 as described below.
EC178 exhibited a growth defect in LB or trypticase soy media (see ref. 10), and experiments comparing this strain to ATCC 11775 were performed using MuellerHinton media in which no defect was detectable. Plasmid pAQ5, bearing the oxyR gene and $90 \%$ of the oxyS gene under their native promoters, was obtained from $\mathrm{G}$. Storz $(11,12)$ and transformed into ATCC 11775 by electroporation. EC166 is strain ATCC 11775 carrying the $\beta$-lactamase plasmid, pBAD18 (13).

Transduction of heavily encapsulated E. coli. Our experience with ATCC 11775 found it to be refractory to modification by many standard molecular biology protocols, including $\lambda$-phage transduction and plasmid transformation following standard $\mathrm{CaCl}_{2}$ starvation protocols. Based on a conjecture that exuberant capsule formation impedes surface interactions necessary for phage attachment, we took advantage of the observation that cold temperatures suppress the activity of enzymes required for capsule formation (14-16). ATCC 11775 cells from overnight cultures were extensively washed with distilled water, suspended at one-fifth or one-tenth the original volume in $0.1 \mathrm{M} \mathrm{CaCl}_{2}$, and maintained for 3-30 days at $4^{\circ} \mathrm{C}$. Cells prepared in this fashion were amenable to transduction with $\lambda$ and $\mathrm{P} 1$ phages and to transformation with supercoiled plasmids by otherwise standard protocols (H. Rosen et al., unpublished data).

Incubation of bacteria with neutrophils for genomic expression profiling. ATCC 11775 cells at twice the desired final concentration were opsonized and temperature adapted by tumbling for 30 minutes at $37^{\circ} \mathrm{C}$ in snap-cap polypropylene tubes $(5 \mathrm{ml}, 12 \times 75 \mathrm{~mm}$, Falcon 352063; Becton Dickson and Co., Franklin Lakes, New Jersey, USA) in HHBSS supplemented with $2 \mathrm{mM} \mathrm{CaCl}_{2}, 1 \mathrm{mM} \mathrm{MgCl}_{2}$, and $10 \%$ autologous serum (native or complement inactivated). Neutrophil phagocytosis was initiated by addition of an equal volume of PMNs, prewarmed for 5 minutes at $37^{\circ} \mathrm{C}$. It should be noted that the requirement for temperature adaptation of bacteria precluded preadherence to neutrophils at low temperature to synchronize phagocytosis. Total reaction volumes ranged from 1 to $4 \mathrm{ml}$. When the effects of preincubation with native versus complement-inactivated serum were to be compared $(t=0)$, opsonized bacteria were diluted with an equal volume of $37^{\circ} \mathrm{C}$ HHBSS (no neutrophils), and RNA isolation was initiated immediately using the same protocol as for neutrophil-containing preparations. At indicated times after addition of neutrophils, 50- $\mu$ l samples were obtained for assessment of phagocytosis and bacterial viability, and the remainder was promptly processed for RNA isolation.

$R N A$ isolation. For method 1, neutrophil-bacteria suspensions were rapidly mixed with an equal volume of hot $\left(95-100^{\circ} \mathrm{C}\right)$ lysis-denaturation buffer. Vigorous vortex mixing for 30 seconds uniformly dispersed the initially inhomogeneous mixture. Polytron homogenization (30 seconds) or sonication (microtip, maximum power, $50 \%$ duty cycle for 3 minutes) at room temperature significantly increased bacterial RNA yields, presumably by facilitating bacterial cell disruption. Lysates could be stored at $-80^{\circ} \mathrm{C}$ either before or after the 
polytron or sonication steps. Typically, lysates were sonicated immediately after vortexing in lysis-denaturation buffer, frozen, and stored for up to 3 days at $-80^{\circ} \mathrm{C}$. Thawed lysates $\left(65^{\circ} \mathrm{C}\right.$ for 3 minutes) were vortex mixed for 30 seconds with 1 vol (based on the original neutrophil-bacteria suspension volume) of chloroform. Centrifugation for 5 minutes at $4^{\circ} \mathrm{C}, 3,400 \mathrm{~g}$ facilitated phase separation. The upper phase was transferred to a new tube and extracted with $1 \mathrm{vol}$ of $0.1 \mathrm{M}$ citrate buffer-saturated phenol, $\mathrm{pH} 4.3$ (P-4682; SigmaAldrich), vortexed for 20 seconds, and 1 vol of chloroform/isoamyl alcohol added (C-0549; Sigma-Aldrich) with vortex mixing for an additional 30 seconds. Following phase separation by centrifugation supernatants were transferred to new tubes, carefully avoiding the flocculent interface. The phenol/chloroform/isoamyl alcohol extraction procedure was repeated twice for a total of three extractions. The volume of the upper phase was determined, mixed with 0.1 vol DEPC-treated sodium acetate $3.0 \mathrm{M}, \mathrm{pH} 5.6,1 \mathrm{vol}$ of isopropanol, and stored for $2-18$ hours at $-20^{\circ} \mathrm{C}$. The RNA pellet, obtained by centrifugation for 45 minutes at $0^{\circ} \mathrm{C}$, $48,000 \mathrm{~g}$, often contained residual nuclease activity and was thus subjected to a de novo RNA purification procedure using a commercial kit (RNAqueous; Ambion Inc., Austin, Texas, USA) employing $1 \mathrm{ml}$ of RNAqueous lysis buffer to suspend the isopropanol pellet. RNA was eluted from the washed Ambion Inc. purification column in two 60- $\mu$ l applications of USP water, heating the capped column for 5 minutes at $70^{\circ} \mathrm{C}$ prior to each elution. Combined eluates in microcentrifuge tubes were precipitated with $2 \mu \mathrm{l}$ pellet paint coprecipitant (Invitrogen Corp., San Diego, California, USA), $12 \mu \mathrm{l}$ DEPCtreated $3.0 \mathrm{M}$ sodium acetate, $\mathrm{pH}$ 5.6, and $360 \mu \mathrm{l} 100 \%$ ethanol, and stored at $-20^{\circ} \mathrm{C}$. RNA was concentrated by microcentrifugation for 30 minutes at $17,000 \mathrm{~g}, 4^{\circ} \mathrm{C}$. All but approximately $20 \mu \mathrm{l}$ of supernatant was aspirated, the pellet was vigorously washed with $0.5 \mathrm{ml}$ cold $75 \%$ ethanol and centrifuged for an additional 15 minutes. All but approximately $20 \mu \mathrm{l}$ of supernatant was aspirat$\mathrm{ed}$, and ethanol on the sides of the tube was concentrated by brief (1-2 seconds) microcentrifugation. Residual ethanol was carefully aspirated using a flame-drawn Pasteur pipette tip. The RNA pellet was dissolved in $5 \mu \mathrm{l}$ USP water and maintained on ice. A sample of RNA $(0.5 \mu \mathrm{l})$ was diluted 40 -fold with $10 \mathrm{mM}$ tris- $\mathrm{HCl}, 1 \mathrm{mM}$ EDTA, pH 8.0 (TE) and analyzed for RNA content (RiboGreen fluorescence assay; Molecular Probes Inc., Eugene, Oregon, USA) and for appearance on nondenaturing ethidium bromide-stained agarose gels. Based on relative intensities of the ribosomal bands it was estimated that typically one-fifth or more of the recovered RNA was bacterial.

For method 2, simpler protocols sufficed for RNA isolations not involving neutrophils. Typically, bacteria were concentrated by centrifugation if necessary and mixed with TRIzol reagent (Life Technologies Inc., Grand Island, New York, USA). RNA yields were dramatically increased by sonic disruption of the bacteria at the expense of increased DNA contamination in the final preparation. RNA could be recovered from the TRIzol mixture either by chloroform extraction and alcohol precipitation as described by the vendor or by dilution with an equal volume of $64 \%$ ethanol and purification on an RNAqueous (Ambion Inc.) column.

Phagocytosis. Fifty microliters of bacteria-neutrophil suspension were diluted tenfold in cold HHBSS. Twenty microliters were further diluted in $450 \mu \mathrm{l}$ HHBSS and maintained on ice. Cells and bacteria were cytocentrifuged onto charged glass microscope slides (ProbeOn Plus; Fisher Scientific Co., Pittsburgh, Pennsylvania, USA). While charged slides retained unphagocytosed bacteria approximately twice as avidly as untreated glass slides, they were still very inefficient, retaining only about $7 \%$ of neutrophil-free bacteria (not shown). Slides were heat fixed, stained $5-30$ seconds with $0.05 \%$ safranin $\mathrm{O}$, rinsed gently, dried, coverslipped, and examined at $\times 1,000$ by light microscopy. Bacteria were considered phagocytosed if observed within the margins of the neutrophil membrane. They were considered to be adherent if adjacent to the neutrophil margin in a tangential orientation. The location of bacteria in the depth dimension was evaluated in selected fields by deconvolution image restoration epifluorescence microscopy, which verified their intracellular location (Deltavision system; Applied Precision Inc., Issaquah, Washington, USA) (TRITC filters: excitation $555 \pm 14 \mathrm{~nm}$, emission $617 \pm 36 \mathrm{~nm}$ ). In general, phagocytosed bacteria appeared to be shorter and plumper than adherent or cell-free bacteria. Slides were scored by counting all neutrophils in ten contiguous oil fields ( $\sim 30$ cells/field), scoring neutrophils as having zero, adherent only (appliqué), one to five, six to ten, or more than ten phagocytosed bacteria. Results were recorded as the percentage of cells in each category.

Respiratory burst activation. Neutrophils and bacteria were incubated as for gene expression profiling except that the medium was supplemented with $100 \mu \mathrm{M}$ ferricytochrome $c$ and, in replicate samples, with bovine superoxide dismutase $(50 \mu \mathrm{g} / \mathrm{ml})$. At indicated times, samples were transferred to an ice-water bath and cleared of particulate material by centrifugation. Cytochrome $c$ reduction was estimated by the increase in absorbance at $550 \mathrm{~nm}$ using an extinction coefficient of $21 \mathrm{mM}^{-1} \mathrm{~cm}^{-1}$. Superoxide production was estimated as superoxide dismutase-inhibitable ferricytochrome $c$ reduction.

Microbial viability. Neutrophil-bacteria suspensions were, if necessary, diluted in HHBSS to neutrophil densities of $5 \times 10^{6}$ cells $/ \mathrm{ml}$ or less, and neutrophils were lysed by tenfold dilution and repetitive pipetting in $0.1 \%$ SDS (previously determined not to affect viability of the E. coli). Lysis of neutrophils at cell densities greater than $5 \times 10^{6}$ cells/ml produced viscous strands, presumably of eukaryotic DNA, that interfered with reproducible dispersion and dilution of bacteria. Subsequent tenfold dilutions were made in M63 salts, and 50- $\mu 1$ samples were plated in molten trypticase soy agar maintained at $50^{\circ} \mathrm{C}$. Alternatively, where indicated in legends to figures and tables, $5 \mu \mathrm{l}$ of lysate dilutions were spread on 
the surface of prepoured nutrient agar plates. For some experiments (see Figure 6), 5- $\mu$ l replicates of each dilution were plated on Mueller-Hinton agar supplemented with $100 \mu \mathrm{g} / \mathrm{ml}$ carbenicillin to select for growth of ATCC 11775 cells carrying the pBAD18-encoded $\beta$-lactamase or $10 \mu \mathrm{g} / \mathrm{ml}$ kanamycin to select for $\triangle o x y R S$ mutants with the $\operatorname{kan}^{\mathrm{R}}$ gene replacement.

Reverse transcription and hybridization. Bacteria-neutrophil RNA samples containing 8-30 $\mu \mathrm{g}$ total RNA in $4.5 \mu \mathrm{l}$ water were mixed with $4 \mu \mathrm{l}$. coli-specific primers in a thin-walled PCR tube, heated to $90^{\circ} \mathrm{C}$, and cooled to $42^{\circ} \mathrm{C}$ in $0.6^{\circ}$-decrements over 20 minutes. After annealing, tubes received $4 \mu 15 \times$ Superscript buffer, 2 $\mu \mathrm{l} 0.1 \mathrm{M}$ dithiothreitol, $2 \mu \mathrm{l}$ proprietary nucleotide mix (StripEZ DNA kit; Ambion Inc.), $2-3 \mu l \alpha \mathrm{P}^{33}$-dATP (Redivue, $10 \mu \mathrm{Ci} / \mu \mathrm{l}, 2,500 \mathrm{Ci} / \mathrm{mmol}$; Amersham Biosciences Corp., Piscataway, New Jersey, USA), and $1.5 \mu \mathrm{l}$ reverse transcriptase (200 u/ $\mu$ l Superscript II; Life Technologies Inc.). Reverse transcription was allowed to proceed for 20 minutes at $20^{\circ} \mathrm{C}$ and then for 2 hours at $42^{\circ} \mathrm{C}$. Products were separated from unincorporated nucleotide on a glass fiber column (High Pure PCR Product Purification Kit; Roche Molecular Biochemicals, Indianapolis, Indiana, USA) with sampling before and after column separation to assess the efficiency of nucleotide incorporation. Effective nucleotide incorporation ranged from 20 to $70 \%$ of input dATP. RNA was rejected as unsatisfactory when incorporation was less than $20 \%$, in which case it was consistently less than $1 \%$. Radiolabeled cDNA was diluted 11 -fold with $10 \mathrm{mM}$ EDTA and denatured for 5 minutes at $95^{\circ} \mathrm{C}$. Within each comparison, the amount of total RNA subjected to reverse transcription was approximately equal. Rejection of any sample based on poor nucleotide incorporation entailed rejection of both samples.

Nylon-based E. coli genomic arrays were purchased from Sigma-Aldrich and wetted according to the supplier's suggestions. Arrays were prehybridized with 10 $\mathrm{ml}$ hybridization solution (Perfect-Hyb Plus; SigmaAldrich) for 5 minutes at $65^{\circ} \mathrm{C}$. Radiolabeled cDNA was carefully added to the hybridization solution, avoiding direct contact with the membranes, and hybridization was allowed to proceed overnight at $65^{\circ} \mathrm{C}$. The hybridized membranes were rinsed three times for 2 minutes at room temperature with wash buffer $(0.5 \times$ SSPE, $0.2 \%$ SDS, $80-100 \mathrm{ml}$ ), and washed three times for 20 minutes at $65^{\circ} \mathrm{C}$ with the same buffer. Washed blots were drained, applied to a filter-paper backing to facilitate handling, and wrapped in plastic cling wrap. Wrapped blots were exposed to a phosphor screen that was exposed for 5-8 days at $4^{\circ} \mathrm{C}$ (Cyclone PhosphorImager System; Packard Instrument Co., Meriden, Connecticut, USA). After each use, blots were stripped using a commercial protocol (StripEZ DNA; Ambion Inc.), wrapped in plastic cling wrap as for imaging, and stored at $4^{\circ} \mathrm{C}$. Blots could be used up to eight times, with limiting factors for further use consisting of gradually diminishing signal intensity, blurring of spot margins, and increasing background signal.
Data analysis. Arrays consisted of adjacent pairs of spots representing full-length DNA from predicted or known ORFs (4,290 spot pairs), genomic DNA standards (24 spot pairs), and 294 deliberately blank spot pairs. Spots were initially located in the pixel array using a custom template (ArrayVisons; Imaging Research Inc., St. Catherines, Ontario, Canada) that was readjusted manually for each array. Signal intensities were collected in a spreadsheet and analyzed as follows. Background was defined to be the tenth percentile of all 4,608 spot pairs, including the 294 blank pairs and the weakest hybridization signals. Backgrounds were subtracted, then all spots were arbitrarily assigned a minimum value of 0.5 times background (to preclude calculation of absurdly high expression ratios consequent to very low denominators). Spot pairs were excluded from analysis if replicate spot intensities varied by more than $30 \%$ from their mean (lack of reproducibility or localized artifacts). Spots were also excluded if the summed intensities of four spots (two experimental and two control) failed to exceed a threshold intensity of three times the sum of the assigned minimum values (exclusion of very low abundance transcripts). Typically, $12 \% \pm 5 \%$ (mean \pm SEM, $n=4$ ) of ORF spots were excluded from analysis in a given experiment. A normalization factor was calculated that would equalize the intensities of the 75th percentile of ORF spot intensities. Normalization factors ranged from 0.85 to $2.11(1.14 \pm 0.38$, mean \pm $\mathrm{SD}, n=9$ ) and generally had a modest effect on analyses.

Ratios of averaged spot intensities for efficiently phagocytic versus poorly phagocytic conditions were determined and recorded as the logarithms. Means and SEs of the means were calculated. A $t$ statistic was calculated by dividing the mean by the SE. The probability of obtaining this $t$ value from random data $(n-1$ degrees of freedom, two-tailed distribution) was determined. Data with $t$ statistics at the $5 \%$ probability level or less were selected for further evaluation. To convey a more intuitive appreciation of changes in expression, data are presented in text and tables as "fold change." For expression ratios greater than one this value is simply the geometric mean (the $n$th root of the product of the $n$ values). For expression ratios less than one it is the reciprocal of the geometric mean expressed as a negative number $(17,18)$. Annotations of gene function were obtained from EcoCyc (19) or from BLAST (National Center for Biotechnology Information; http://www.ncbi.nlm.nih.gov) searches based on predicted peptide sequences, unless otherwise noted by citation. Message abundance for cpxP was estimated by hybridization intensity with the nucleotide sequence encoded by the predicted ORF b3914, which actually represents the terminal threefourths of the sequence for $\operatorname{cpxP}(20)$.

Microbial survival after incubation with neutrophils (see Figure 5) was expressed as a percentage of the initial inoculum, and statistical analysis was performed on the logarithmically transformed data, using a twoway ANOVA design and either Bonferroni's $t$ test or the Student-Newman-Keuls test for multiple comparisons 
(SigmaStat; Jandel Scientific, San Rafael, California, USA). ANOVA-based comparisons of microbial strain survival after phagocytosis by normal and oxidase-deficient normal neutrophils (see Figure 6) were performed separately for each indicated time period.

Real time PCR. RNA was reverse transcribed using commercial protocols and reagents (Omniscript Reverse Transcription Kit; QIAGEN Inc., Valencia, California, USA). cDNA was amplified using reagents (Sybr Green PCR master mix), protocols, and instrumentation (ABI Prism 7700) supplied by Applied Biosystems Inc. (Foster City, California, USA). Real-time PCR standards were prepared by PCR amplification of genomic DNA from ATCC 11775. Purity of the standards was assessed by agarose gel electrophoresis, and quantitation was by measurement of absorbance at $260 \mathrm{~nm}$. Primers were as described previously $(21,22)$ or designed using Primer (Genetics Computer Group, University of Wisconsin, Madison, Wisconsin, USA) or Vector NTI software (InfoMax Inc., Bethesda, Maryland, USA) specifying primer annealing temperature of $63-68^{\circ} \mathrm{C}$ and product length of 100-150 nucleotides, as suggested by Applied Biosystems. Primer sequences are given in Table 1.

\section{Results}

Selection of comparison conditions for expression profiling was governed by a desire to characterize responses specifically elicited by phagocytosis, as opposed to those elicited by exposure to serum, temperature shifts, or extracellular effects of neutrophils. It has been determined that an intact complement system is critical for neutrophil-mediated phagocytosis and killing of encapsulated strains of E. coli $(23,24)$. Accordingly, we compared responses from bacteria that had been opsonized with $10 \%$ fresh autologous serum (complement system intact) with bacteria that had been opsonized with $10 \%$ heated $\left(56^{\circ} \mathrm{C}, 30\right.$ minutes, complement-inactivated) serum.

Phagocytosis and microbial viability. Figure 1 illustrates the neutrophil responses to $E$. coli opsonized with either native or complement-inactivated serum. Phagocytosis was scored as described in Methods. Incubation of native serum-opsonized bacteria with PMNs for 7 minutes resulted in $2 \% \pm 2 \%$ of PMNs with no internalized or surface-associated bacteria, $40 \% \pm 7 \%$ of PMNs with one to five ingested bacteria, and $58 \% \pm 8 \%$ of PMNs with more than five ingested bacteria. In contrast, opsonization with complement-inactivated serum resulted in $68 \% \pm 4 \%$ of PMNs with no internalized bacteria, $28 \% \pm 4 \%$ of PMNs with surface-associated (appliqué) bacteria, $2 \% \pm 1 \%$ of PMNs with one to five ingested bacteria, and $2 \% \pm 1 \%$ of PMNs with more than five ingested bacteria. Under these conditions, opsonzation with fresh serum elicited a superoxide response of $39 \pm 1 \mathrm{nmol}$ per $5 \times 10^{7}$ PMNs per 7 minutes, while opsonization with complement-inactivated serum elicited a response of $16 \pm 4 \mathrm{nmol}$ per $5 \times 10^{7}$ PMNs per 7 minutes (mean \pm SEM, $n=3$ ). Bacterial viability after 7 minutes of incubation with PMNs was $51 \% \pm 12 \%\left(2.5 \pm 1.0 \times 10^{8}\right.$ bacteria $\left./ \mathrm{ml}\right)$ of the initial inoculum $\left(4.9 \pm 0.9 \times 10^{8} \mathrm{bacteria} / \mathrm{ml}\right)$ in the presence of native serum and $112 \% \pm 17 \%\left(5.2 \pm 1.3 \times 10^{8}\right.$ bacteria $\left./ \mathrm{ml}\right)$ in the presence of complement-inactivated serum $(P=0.01, n=5$, paired $t$ test $)$.

Expression profiles from phagocytosed bacteria. RNA was prepared from neutrophil-bacteria mixtures, reverse transcribed, and hybridized to a genome array for E. coli MG1655 as described in Methods. Examination of the effects of serum alone, native versus complement-inactivated, on gene expression $(n=4)$ identified just 119 of 4,290 ORFs where the $t$ statistic $(P<0.05)$ screen for differential gene expression was positive. Of these "positive" ORFs, the magnitude of the difference from unity exceeded $60 \%$ (fold change $<-1.6$ or $>1.6$, data not shown) for just one, thrA (fold change $=-1.8, n=3, P=0.03$ ).

In contrast, when RNA was obtained from bacteria incubated for 7 minutes with neutrophils $(n=5), 486$ ORFs screened positive by the $t$ distribution criterion with geometric mean changes in expression ranging from +8.9 to -6.8 . Of these ORFs, difference from unity of expression changes exceeded $60 \%$ for 28 ORFs with increased expression and for 49 ORF's with decreased expression. The 30 most differently expressed ORFs from each extreme are described in Tables 2 and 3.

As described in Table 2, one-third of transcripts with increased abundance following phagocytosis (10 of 30) are among a group of genes affected by hydrogen peroxide-derived stresses. Eight are regulated, at least in part, by the OxyR transcription factor. These include $d p s$, ahpF, ahpC, trxC, kat G, hemH, trxB, and grxA (25). Two genes, $y f i A$ and soxS, are $\mathrm{H}_{2} \mathrm{O}_{2}$ responsive in both wild-type bacteria and oxyRS mutants, suggesting that the $\mathrm{H}_{2} \mathrm{O}_{2}$ response is OxyR independent (25). Six other genes appear to be activated by stresses other than hydrogen peroxide and include $\operatorname{cpxP}$ (misfolded

Table 1

Primer sequences for real-time PCR determinations

\begin{tabular}{|c|c|c|c|c|c|c|}
\hline Gene & Sense & $\mathrm{Tm}$ & Antisense & $\mathrm{Tm}$ & $\begin{array}{l}\text { Product } \\
\text { size } n t\end{array}$ & Source \\
\hline$a h p C F$ & CCGCAGGGTATCATCCAG & 50.9 & TTAGCCGGGCAAACTTCA & 51.6 & 128 & $(22)$ \\
\hline$d p s$ & CAAAACCCCGCTGAAAAGTTAC & 54.6 & GATATCTGCGGTGTCGTCATCT & 53.2 & 142 & (22) \\
\hline katG & GCCGATCTACAACCCGACCGAGCAGG & 69.5 & GCCCAGGCCACCGATACCAGCTCACT & 69.2 & 99 & $(53)$ \\
\hline $\operatorname{oxy} R$ & TTGAGTACCTGGTGGCATTGGCTGA & 63.3 & ATCACGCCCAGCTCATCTTCCAGC & 64.3 & 121 & Vector NTI \\
\hline oxyS & ACGGAGCGGCACCTCTITAAACCCT & 63.2 & CСTGGAGATCCGCAAAAGTT & 50.1 & 100 & Vector NTI \\
\hline $\operatorname{trxC}$ & TGCGGTCACGACTTGTITGACGGAGA & 67.1 & CGGTGCCCAGAAGTCGATCACCACAG & 68.0 & 105 & (53) \\
\hline
\end{tabular}



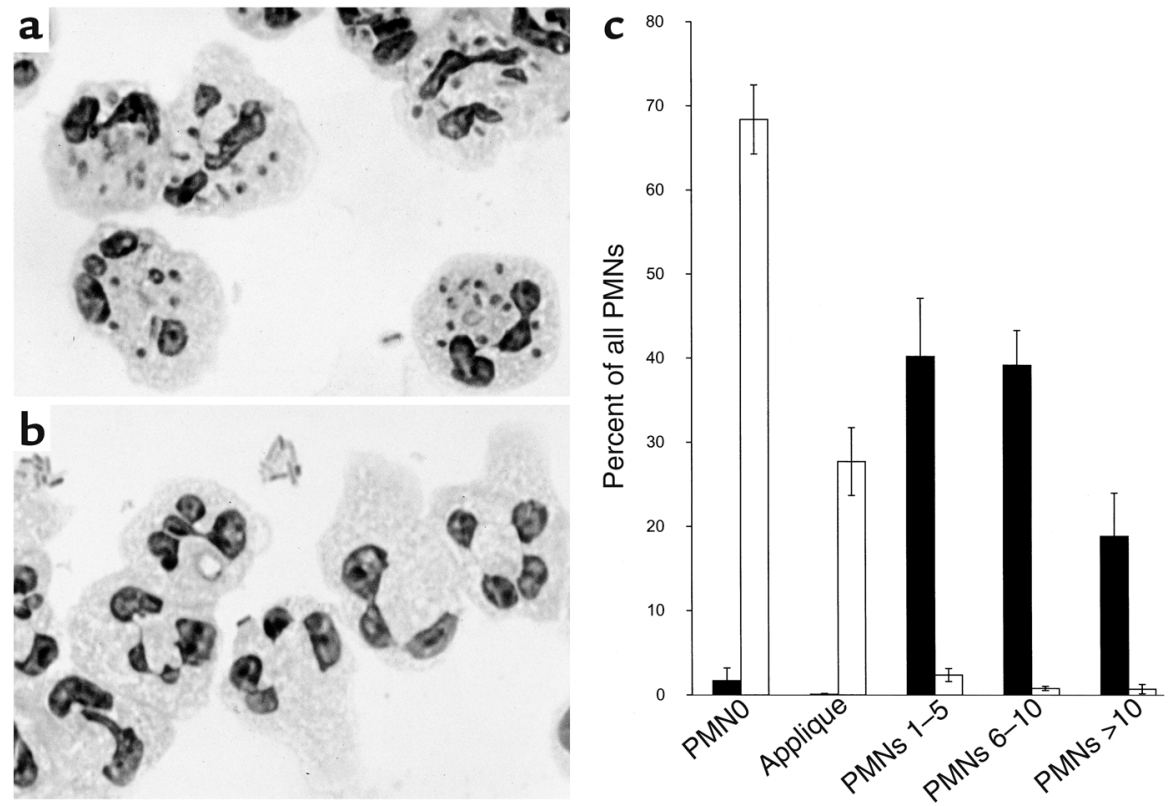

\section{Figure 1}

Complement requirement for phagocytosis. Conditions for phagocytosis were as described in Methods and the legend for Table 2. After 7 minutes of tumbling at $37^{\circ} \mathrm{C}$, bacteria-neutrophil suspensions were diluted in cold HHBSS and deposited on charged microscope slides by cytocentrifugation. Slides were stained with Safranin, and neutrophils were scored for association with bacteria as described in Methods. (a) Neutrophil interactions with E. coli opsonized by fresh autologous serum. (b) Neutrophil interactions with $E$. coli opsonized in parallel by complement-inactivated (30 minutes at $56^{\circ} \mathrm{C}$ ) autologous serum. Bacteria are agglutinated but not ingested. Most neutrophils contain no bacteria. The neutrophil in the center of the field has a tangentially adherent (appliqué) bacterium. (c) Frequency histogram of neutrophil-bacteria associations, as described in Methods. Black bars: bacteria opsonized by native serum; white bars: bacteria opsonized by complement-inactivated serum. Error bars reflect the SEM of data from five experiments.

and 31 genes were identified after 7 minutes of phagocytosis (data not shown). Among these was $g \ln G \quad(-1.5$-fold change, $P=0.03$ ), which encodes NtrC itself. All but one of the mRNA's in the NtrCregulated group (yeaH) exhibited decreased abundance. Additional NtrC-regulated operons were identified after longer exposures of bacteria to phagocytic conditions (see below). These, too, exhibited decreasing abundance with phagocytosis.

One prominent stress response gene, relA, exhibited modestly diminished mRNA abundance in phagocytosed bacteria. The gene relA is a central mediator of the stress response to amino acid starvation, the stringent response.

Alternative measures of $m R N A$ abundance. Since quantitative features of array analysis are uncertain and may fail to correlate quantitatively with other measures, such as primer extension, Northern analysis, or quantitative PCR, some key transcripts were evaluated by real-time PCR

periplasmic proteins, regulated by $c p x A$ stress response), osmB (hyperosmolarity), ppiA (regulated by cpxA stress response), b1826 ( $m g r B$, magnesium limitation), htpX (heat shock protein), and $\operatorname{csp} D$ (cold shock, inhibits DNA replication). Five genes bear an established or predicted relationship to nitrogen metabolism, b2833, napD and napA, trpE, and yadI. One gene codes for a component of a putative ATPbinding cassette $(A B C)$ transporter. Eight ORFs coded for peptides of unknown function or with only homology-based presumptive functional characterizations. ORFs with diminished mRNA abundance (Table 3) appeared with striking frequency to be related to nitrogen metabolism and transport. Twenty-five of the 30 most differentially expressed mRNAs bear a relationship to nitrogen or nitrogen amino acid metabolism. Thirteen (13 of 25 ) are regulated in their expression by the NtrC transcriptional component of the NtrB/NtrC sensor kinase system (26). Twelve ORFs (12 of 30) code for established or putative components of $\mathrm{ABC}$ transport systems. Eleven of the $12 \mathrm{ABC}$ components are in the nitrogen-related group. In a comprehensive study of NtrC/NAC-regulated genes, 25 operons and 75 genes were identified as dependent on these transcriptional modifiers (26). In the current study, 17 operons analysis as described in Methods. The fold difference for mRNA abundance after 7 minutes of phagocytosis was ahpCF: 5.4; dps: 8.8; katG: 4.4; and trxC: $23(n=1)$. The mRNA for $a b p C$ and $a b p F$ is a single transcript and was evaluated with a primer set for $a b p C$ as described in Table 1 . With the exception of $\operatorname{tr} x C$, the fold change estimates by PCR agreed well with estimates of hybridization intensity on the genomic arrays. Realtime PCR analysis was also performed for oxyS, which encodes a small OxyR-responsive regulatory RNA not represented in the genomic array (not an ORF or protein-coding sequence) (27-31). There was a 14-fold increase in abundance of oxyS RNA under phagocytic conditions $(n=1)$, lending further support to the presence of a strong OxyR response in phagocytosed E. coli.

Time dependence of $O x y R$ - and NtrC-regulated gene expression. The microbial response to phagocytosis would be expected to vary with time. Accordingly, array analysis was performed with bacteria that had been exposed to neutrophils for $15(n=4)$ and 30 minutes $(n=4)$. The results for $a h p C, a h p F, d p s$, hem $H, k a t G, o x y R$, and trx $C$ are shown in Figure 2a. For $a b p C$, $a h p F, d p s$, hemH, and $\operatorname{trx} C$ the peak ratio of mRNA abundance was at 7 minutes, with either a mild dip or plateau thereafter. The oxyR mRNA expression ratios were unaffected by 
phagocytosis throughout this period of observation (Figure 2a, filled circle data points with error bars).

Analysis of gene expression data at 15 and 30 minutes identified systematic changes in the expression ratios for NtrC-regulated operons not prominent at $7 \mathrm{~min}$ utes. One, AstCADBE (Figure 2b), was characterized recently as participating in arginine catabolism (32). The other operon, b1012 $\rightarrow$ b1008 (Figure 2c), has been identified as NtrC regulated (26) and may participate in pyrimidine catabolism (33).

Contribution of neutrophil oxidative metabolism to gene expression changes. The prominence of the OxyR response to phagocytosis presumably reflects a response to $\mathrm{H}_{2} \mathrm{O}_{2}$ generated by the neutrophil respiratory burst oxidase. Neutrophils from individuals with chronic granulomatous disease (CGD) fail to assemble a functional oxidase and typically generate less than $1 \%$ of the normal amount of respiratory burst products. When bacteria were phagocytosed by CGD neutrophils, increased expression of OxyR-regulated mRNA's was blunted, as indicated in Figure 3, for $a h p C, a h p F, d p s, k a t G, \operatorname{tr} x C$, and $b e m H$. RNA expression ratios were not significantly different for the two OxyR-regulated genes, $\operatorname{tr} x B$ and gr $x A$, or for the non$\mathrm{OxyR}, \mathrm{H}_{2} \mathrm{O}_{2}$-responsive genes, $y$ fi $\mathrm{A}$ and soxS.

Table 2

Genes with increased mRNA expression ratios

\begin{tabular}{|c|c|c|c|c|c|c|c|c|}
\hline $\begin{array}{l}\text { Gene } \\
\text { name }\end{array}$ & b no. & $\begin{array}{l}\text { Fold } \\
\text { change }\end{array}$ & $P$ value & & Features & & Location & Comment \\
\hline$d p s$ & b0812 & 8.9 & 0.0001 & oxyR & & & cytoplasm & $\begin{array}{l}\text { DNA binding protein of starvation, } \\
\text { hydrogen peroxide stress }\end{array}$ \\
\hline$a h p F$ & b0606 & 6.4 & 0.002 & oxyR & & & cytoplasm & alky hydroperoxide subunit $F$ \\
\hline$c p \times P$ & b3914 & 3.8 & 0.0003 & & stress & & periplasm & $\begin{array}{l}\text { cpxP, stress response to misfolded } \\
\text { periplasmic protein }\end{array}$ \\
\hline $\operatorname{ahpC}$ & b0605 & 3.8 & 0.0004 & oxyR & & & cytoplasm & alky hydroperoxide subunit C \\
\hline$y f i A$ & b2597 & 3.8 & 0.004 & & $\mathrm{H} 2 \mathrm{O} 2$ & & cytoplasm & $\begin{array}{l}\text { putative yhbH o54 modulator - ribosome } \\
\text { organization in stationary phase, nitrogen metabolism }\end{array}$ \\
\hline b1172 & b1172 & 3.7 & 0.02 & & & & unknown & unknown \\
\hline $\operatorname{trx} C y f i G$ & b2582 & 3.3 & 0.001 & oxyR & & & cytoplasm & thioreductase $\mathrm{C}$ \\
\hline $\operatorname{soxS}$ & b4062 & 2.8 & 0.02 & & $\mathrm{H} 2 \mathrm{O} 2$ & & cytoplasm & superoxide sensing \\
\hline katG & b3942 & 2.6 & 0.001 & oxyR & & & cytoplasm & catalase \\
\hline b2833 & b2833 & 2.6 & 0.02 & & & $\mathrm{~N}_{2}$ & unknown & $\begin{array}{l}\text { hypothetical lipoprotein, distantly related } \\
\text { to V. cholera nitrate reductase }\end{array}$ \\
\hline $\operatorname{osm} B$ & b1283 & 2.4 & 0.03 & & stress & & outer memb & $\begin{array}{l}\text { outer membrane lipoprotein - induction } \\
\text { by hyperosmolarity and during stationary phase }\end{array}$ \\
\hline napD & b2207 & 2.2 & 0.02 & & & $\mathrm{~N}_{2}$ & periplasm & $\begin{array}{l}\text { post-translational modification of napA } \\
\text { (see below) essential for napA function }\end{array}$ \\
\hline $\operatorname{trp} E$ & b1264 & 2.2 & 0.03 & & & $\mathrm{~N}_{2}$ & cytoplasm & $\begin{array}{l}\text { anthranilate synthase component I: } \\
\text { biosynthesis of tryptophan from chorismate }\end{array}$ \\
\hline ppiA & b3363 & 2.1 & 0.009 & & stress & & periplasm & $\begin{array}{l}\text { peptidyl-prolyl cis-trans isomerase } \mathrm{A} \text { (rotamase A) } \\
\text { - protein folding - regulated by cpx stress }\end{array}$ \\
\hline hemH & b0475 & 2.1 & 0.002 & oxyR & & & cytoplasm & ferrochelatase \\
\hline b3095 & b3095 & 2.1 & 0.002 & & & & unknown & unknown, DedA family conserved domain \\
\hline b1826 & b1826 & 2.0 & 0.04 & & stress & & unknown & mgrB magnesium limitation \\
\hline napA & b2206 & 2.0 & 0.02 & & & $\mathrm{~N}_{2}$ & periplasm & periplasmic nitrate reductase \\
\hline yqjF & b3101 & 2.0 & 0.04 & & & & unknown & unknown, conserved domain SURF4, SURF4 family \\
\hline$g / p F$ & b3927 & 1.9 & 0.003 & & & & inner memb & glycerol pore in inner membrane \\
\hline b1171 & b1171 & 1.9 & 0.05 & & & & unknown & unknown \\
\hline$h t p X$ & b1829 & 1.8 & 0.004 & & stress & & inner memb & heat shock protein \\
\hline apaG & b0050 & 1.8 & 0.04 & & & & unknown & $\mathrm{cf}$ apaH and stress responses \\
\hline $\operatorname{csp} D$ & b0880 & 1.7 & 0.02 & & stress & & cytoplasm & cold shock protein, inhibits DNA replication \\
\hline $\operatorname{tr} x B$ & b0888 & 1.7 & 0.03 & oxyR & & & cytoplasm & thioreductase B \\
\hline yejO & b2190 & 1.7 & 0.004 & & & & unknown & $\begin{array}{l}\text { putative ATP-binding component } \\
\text { of a transport system }\end{array}$ \\
\hline $\operatorname{grx} A$ & b0849 & 1.6 & 0.03 & oxyR & & & cytoplasm & thioredoxin, glutaredoxin \\
\hline $\operatorname{infA}$ & b0884 & 1.6 & 0.02 & & & & cytoplasm & protein chain initiation factor IF-1 \\
\hline yadl & b0129 & 1.6 & 0.01 & & & $\mathrm{~N}_{2}$ & unknown & $\begin{array}{c}\text { Phosphotransferase Systems (PEP-dependent PTS) } \\
\text { subunit of EllAga }\end{array}$ \\
\hline
\end{tabular}

Escherichia coli $\left(10^{9}\right.$ cells per $\left.\mathrm{ml}\right)$ were opsonized with $10 \%$ native or complement-inactivated serum for 30 minutes at $37^{\circ} \mathrm{C}$ as described in Methods. Phagocytosis was initiated by the addition of an equal volume of neutrophils $\left(10^{8}\right.$ cells $\left./ \mathrm{ml}\right)$ in warm $\left(37^{\circ} \mathrm{C}\right) \mathrm{HHBSS}$. After tumbling for 7 minutes at $37^{\circ} \mathrm{C}, \mathrm{RNA}$ was extracted from $4 \mathrm{ml}$ of suspension, reverse transcribed, and hybridized to a DNA array representing 4,290 ORFs from the genome of $E$. coli strain K12, MG1655. Results are the geometric mean of expression ratios (phagocytosed vs. extracellular bacteria) from five paired array experiments. The table lists in descending order the most prominently expressed genes with "b no." referring to the system of consecutive enumeration of predicted ORFs in the genome for E. coli strain MG1655, beginning with b0001 $=t h r L$ in the direction of thrA. $P$ values are from the distribution of the two-tailed $t$ statistic for difference from an expression ratio of 1. Features include genes of the oxyR regulon (oxyR), hydrogen peroxide-responsive genes not in the oxyR regulon $\left(\mathrm{H}_{2} \mathrm{O}_{2}\right)$, other genes known to respond to environmental stresses (stress), and genes that participate in metabolism of nitrogenous compounds $\left(\mathrm{N}_{2}\right)$. memb, membrane. 
Table 3

Genes with diminished mRNA expression ratios

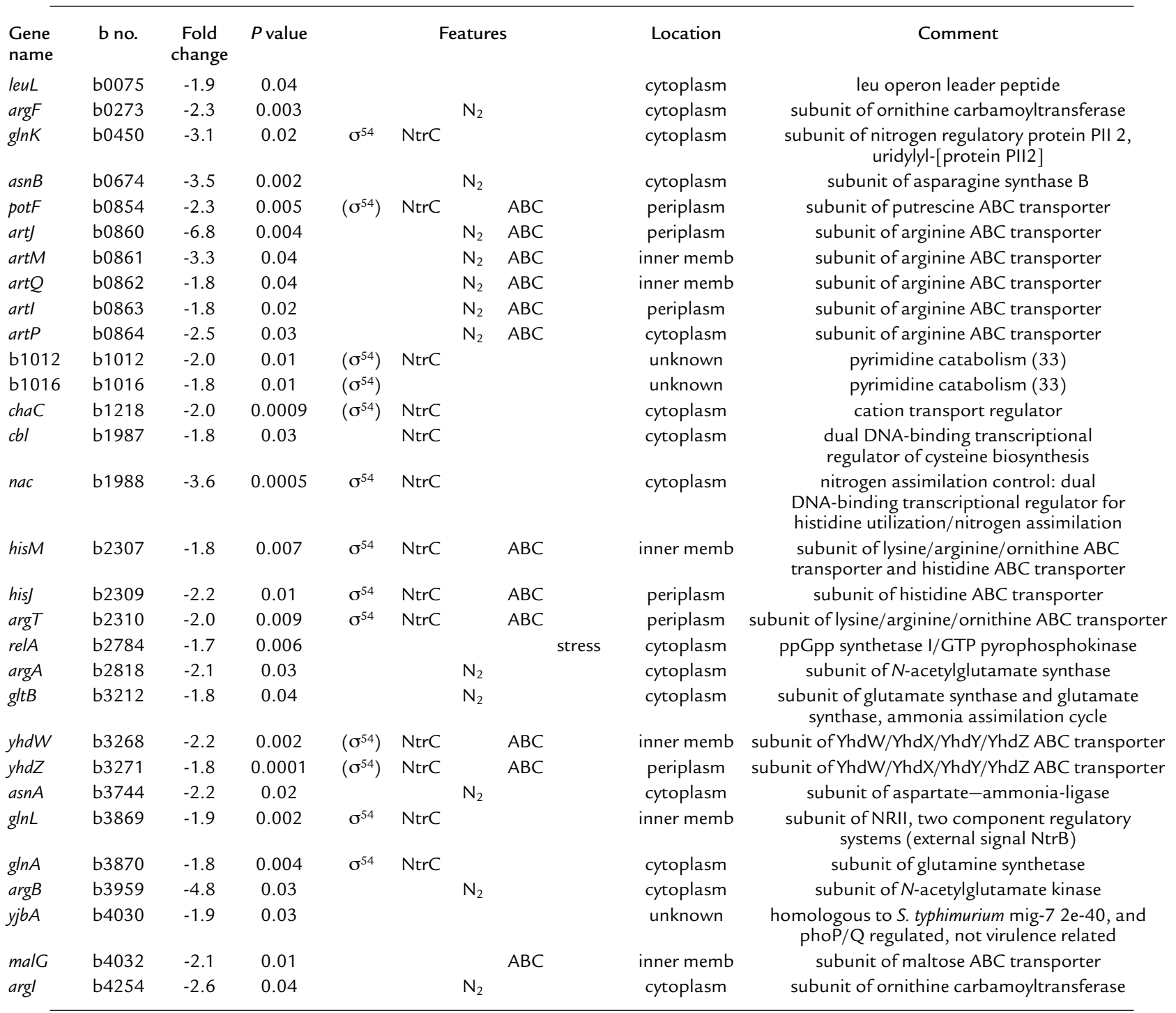

Genes with diminished mRNA expression ratios. Conditions were as described in Table 2. Genes are listed in order of ascending b numbers, which reflect their relative position in the chromosome. Features include proven, $\sigma^{54}$, or computationally predicted, $\left(\sigma^{54}\right)$, transcription by the $\sigma^{54}$ alternative transcription factor, regulation by the $\mathrm{NtrC}$ transcription factor $(\mathrm{NtrC})$, participation in other aspects of nitrogen metabolism $\left(\mathrm{N}_{2}\right)$, participation in $A B C$ transport systems, or response to other stress (stress).

In addition to the hydrogen peroxide-responsive genes, several other response patterns were identified. One group of mRNA's, like those of the OxyR regulon, exhibited increased abundance during phagocytosis by normal but not CGD neutrophils. These genes have not been identified as $\mathrm{H}_{2} \mathrm{O}_{2}$ responsive and presumably respond to other aspects of the neutrophil respiratory burst (Figure 4). Prominent among these is $c p x P$, both a regulator and a product of the $\operatorname{cpxA} / R$ sensor kinase system that mediates stress responses to misfolded proteins in the periplasmic space. Similar effects, albeit of lesser magnitude, were observed for b1172, napA, and $n a p D$ (all described in Table 2), and $y f i D$ (pyruvate formate-lyase component) (34-36).

Conversely, abundance of mRNA's for dinJ (DNAdamage inducible) (37-39) and asr (acid stress response)
(40), $p p d C$ (prepilin peptidase dependent), $s d h D$ (subunit of succinate dehydrogenase), b2334 (hypothetical protein, "pilus"), and $t h r B$ (subunit of homoserine kinase) is more strikingly increased in bacteria phagocytosed by CGD neutrophils. Stress response mRNA expression profiles have been described for dinJ and asr $r$ however, detailed functions for the gene products are not known. The increased expression of the acid stress response gene, as $r$, in the CGD neutrophil environment is consistent with the proposal that CGD phagocytic vacuoles undergo enhanced degrees of acidification following particle ingestion $(41,42)$.

A few genes with increased abundance during phagocytosis, pstA (phosphate starvation induced, subunit of phosphate ABC transporter) and b2833 (Table 2), were about equally affected during normal 
and CGD phagocytosis. Similarly, many genes regulated by the NtrC transcription factor, so prominent in Table 3, appear to express equal degrees of decreased abundance in response to phagocytosis by both normal and CGD neutrophils.

Neutrophil-mediated killing of oxyRS mutants. The OxyR response is prominent in $E$. coli phagocytosed by normal, but not CGD (NADPH oxidase-deficient) neutrophils. The protein products of genes induced by OxyR would be expected to confer a measure of protection from oxidants such as hydrogen peroxide, organic peroxides, and, possibly, myeloperoxidase-generated oxidants such as $\mathrm{HOCl}$. The antimicrobial components of the phagosome are diverse, however, and the capacity of the OxyR regulon to affect bacterial survival in neutrophils is not clear. An oxyRS mutant of ATCC 11775, designated EC178, was constructed by $\mathrm{P} 1$ transduction. The oxyR deficiency in EC178 was complemented by transformation with plasmid $\mathrm{PAQ} 5$ to give strain EC189. A phenotype for these constructs with respect to $\mathrm{H}_{2} \mathrm{O}_{2}$ sensitivity is illustrated in Figure 5a. The oxy $R$ mutant, EC178, consistently demonstrated greater sensitivity to $\mathrm{H}_{2} \mathrm{O}_{2}$ (zone size: $36 \pm 2 \mathrm{~mm}$, mean $\pm \mathrm{SEM}, n=3$ ) than the parent strain $(19 \pm 0.3 \mathrm{~mm})$. Complementation with plasmid PAQ5 (EC189) reversed the phenotype $(19 \pm 1 \mathrm{~mm})$.

This $\mathrm{H}_{2} \mathrm{O}_{2}$ susceptibility pattern was reprised when these bacteria were incubated with neutrophils under conditions described in Figure 5. No differences in microbicidal activity were observed after 15 minutes of incubation (data not shown). However, by 30 minutes and 60 minutes a statistically significant $(P<0.001)$ hypersusceptibility of the $\triangle$ oxyRS mutant was evident.
Complementation of the $\Delta o x y R S$ mutant with the pAQ5 plasmid caused the oxyRS phenotype to revert to wildtype. When neutrophils were omitted from the incubation mixture, growth of the oxy $R S$ strain was similar to that of the parent with a two- to threefold increase in numbers during the 1 hour incubation with serum (not shown).

Oxidase-deficient neutrophils were used in a competitive survival assay to evaluate nonoxidative contributions to neutrophil-mediated killing of $\triangle$ oxyRS $E$. coli (Figure 6). Strain EC166 was constructed by introducing a plasmid-encoded $\beta$-lactamase gene into ATCC 11775 as described in Methods. Equal inocula of EC166 (wild-type, carbenicillin resistant) and EC178 $\left(\Delta o x y R S, \operatorname{kan}^{\mathrm{R}}\right)$ were mixed and opsonized in the usual manner. At intervals after the addition of either normal donor (Figure 6a) or oxidase-deficient neutrophils (Figure 6b), samples were lysed and diluted. Portions of each dilution were plated on media selective for either wild-type or $\triangle o x y R S$ survivors. For normal neutrophils (Figure 6a), the relationship between survival of EC166 and $\triangle$ oxyRS bacteria after phagocytosis was similar to that described for ATCC 11775 in Figure 5a (I, II). As observed previously for ATCC 11775 (7), oxidase-deficient neutrophils killed EC166 as efficiently as did normal neutrophils. Oxidase-deficient neutrophils, however, killed the $\triangle$ oxyRS strain significantly less well than did normal neutrophils $(P<0.05$ at 30 and 60 minutes, Student-Newman-Keuls test for multiple comparisons), suggesting a significant contribution of oxidative antimicrobial systems to the killing of the $\Delta$ oxyRS strain. Although experiments with oxidase-deficient neutrophils suggest a trend toward

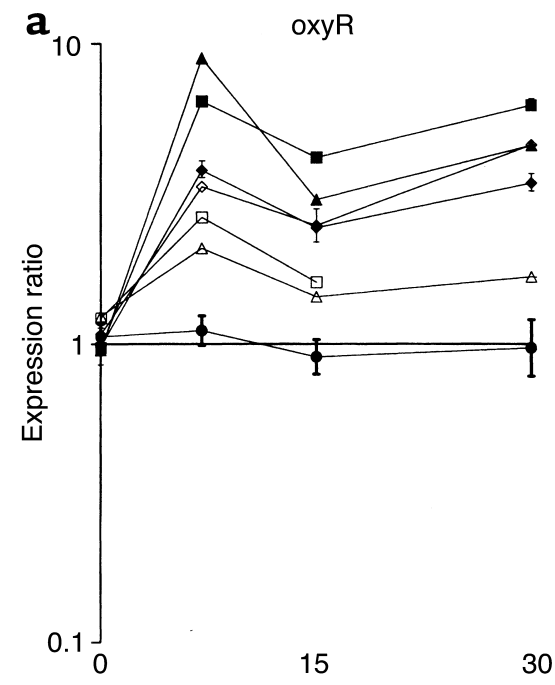

15
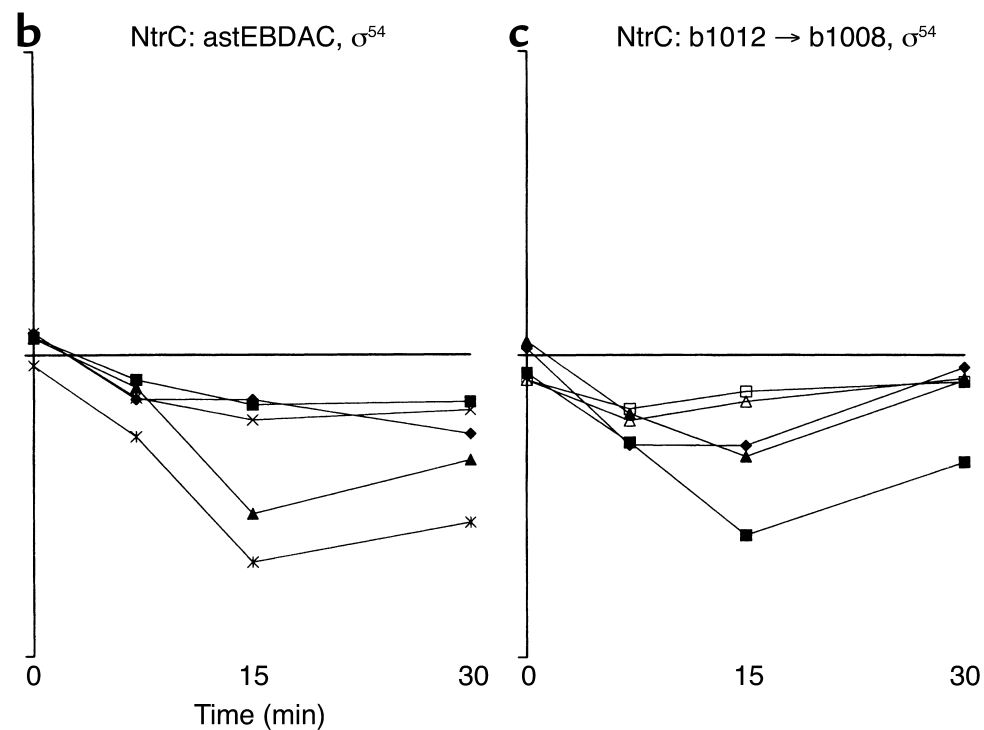

Figure 2

Variations in gene expression with time of phagocytosis. Data from genomic DNA arrays prepared with RNA from bacteria at the conclusion of the preopsonization step $(t=0, n=4)$ and 7 minutes $(n=5), 15$ minutes $(n=4)$, and 30 minutes $(n=4)$ after the addition of neutrophils. (a) Expression ratios for prominent genes of the oxyR regulon: $a h p C$ (filled diamonds), $a h p F$ (filled squares), dps (filled triangles), hemH (open triangles), katG (open squares), $\operatorname{trxC}$ (open diamonds), and oxy $R$ (filled circles with error bars reflecting SEM). (b) Expression ratios for genes of the ast operon (32) regulated by the $\mathrm{NtrC}$ transcription factor (26), astEBDAC: astE (diamonds), astB (squares), astD (triangles), astA (X's), and astC (asterisks). (c) A newly described NtrC-regulated operon of unknown function b1012 $\rightarrow$ b1008, possibly pyrimidine metabolism (26, 33): b1012 (filled diamonds), b1011 (filled squares), b1010 (filled triangles), b1009 (open triangles), b1008 (squares). 


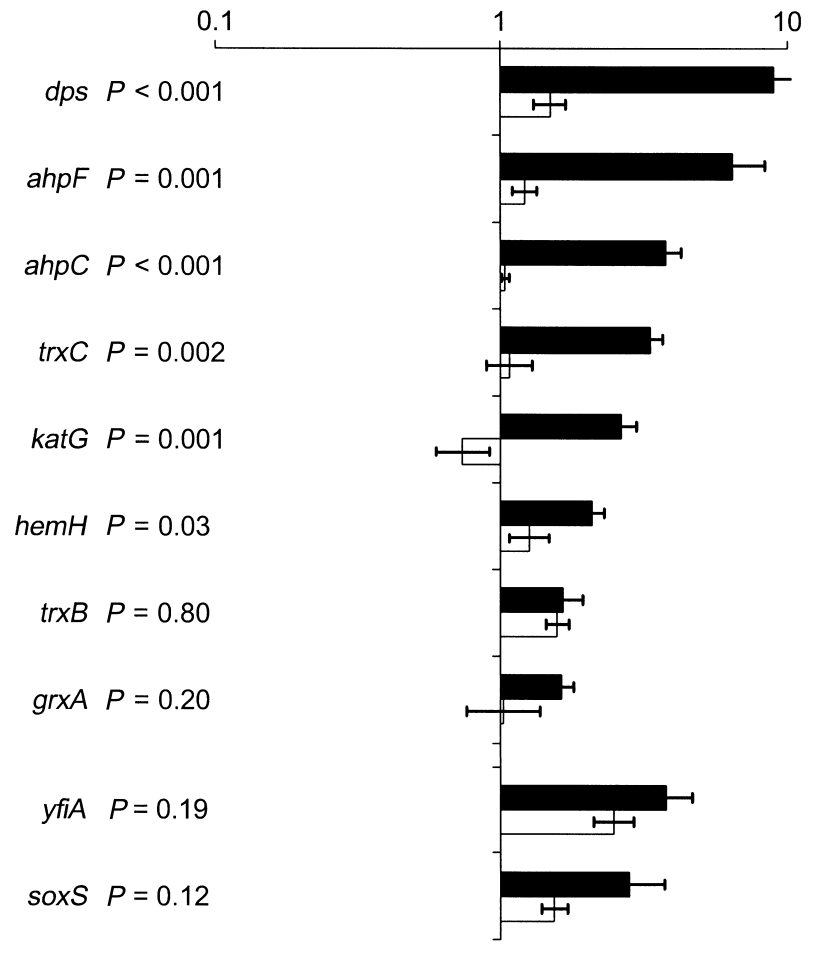

Figure 3

Comparison of expression ratios for bacterial $\mathrm{H}_{2} \mathrm{O}_{2}$-responsive genes after phagocytosis by normal or phagocyte oxidase-deficient neutrophils. Expression ratios for selected $\mathrm{H}_{2} \mathrm{O}_{2}$-responsive E. coli genes 7 minutes after initiation of phagocytosis by normal (filled bars, $n=5$ ) or phagocyte oxidase-deficient (open bars, $n=4$ ) neutrophils. Error bars reflect the SEM. $P$ values adjacent to the gene labels are for the two-tailed $t$ test comparison of data for each type of neutrophil.

hypersusceptibility of the $\Delta o x y R S$ strain to nonoxidative antimicrobial systems (Figure 6b, dashed line), this difference was not statistically significant.

\section{Discussion}

Phagocytes sequester microbes in a vacuole where the environment would be expected to vary according to metabolic interactions specified by surface structures of the both the phagocyte and the microbe. Microbial secretions and metabolic products may further modify phagocyte behavior and phagosomal contents. Thus, an ingested organism would encounter an environment expected to vary with time, opsonic conditions, and the nature of its own metabolism and structural characteristics. Despite the plethora of variables, a paradigm has generally been accepted as typical for neutrophil-mediated phagocytosis and killing of serum-opsonized bacteria $(43,44)$. Contact between opsonins deposited on the microbe and receptors on the neutrophil membrane trigger the assembly of a membrane-associated oxidase that efficiently transfers electrons from cytosolic NADPH to dissolved molecular $\mathrm{O}_{2}$ at the cell surface to form the superoxide anion, $\mathrm{O}_{2}^{-}$. The abrupt increase in oxygen consumption is designated the respiratory burst. Superoxide is unstable and spontaneously decomposes to $\mathrm{H}_{2} \mathrm{O}_{2}$ and $\mathrm{O}_{2}$.
Interactions among $\mathrm{O}_{2}{ }^{-}$and $\mathrm{H}_{2} \mathrm{O}_{2}$ may generate additional oxygen species engendering a highly oxidizing environment. Also, coincident with or soon after initiation of phagocytosis, preformed cytosolic granules fuse with the vacuolar membrane, discharging antimicrobial proteins and peptides into the newly formed compartment. Catalysis by the granule enzyme myeloperoxidase leads to the $\mathrm{H}_{2} \mathrm{O}_{2}$-mediated oxidation of ambient $\mathrm{Cl}^{-}$to highly microbicidal $\mathrm{HOCl}$. Sequestration of the microbe from essential nutrients and trace elements, together with secretion of protons to lower the $\mathrm{pH}$, amplify the antimicrobial properties of the compartment. The resultant environment is inimical to microbial survival and typically results in the death of the ingested microbe.

While exceptions to the paradigm are well described (Legionella, Mycobacterium tuberculosis, Listeria, Yersinia, and others), Escherichia coli is typical in that, when appropriately opsonized, the organism is efficiently killed by neutrophils. Yet, despite this susceptibility, wild-type E.coli strains are also pathogenic, causing urinary tract infections, several forms of enteric disease, septic arthritis, and bacteremic septic shock.

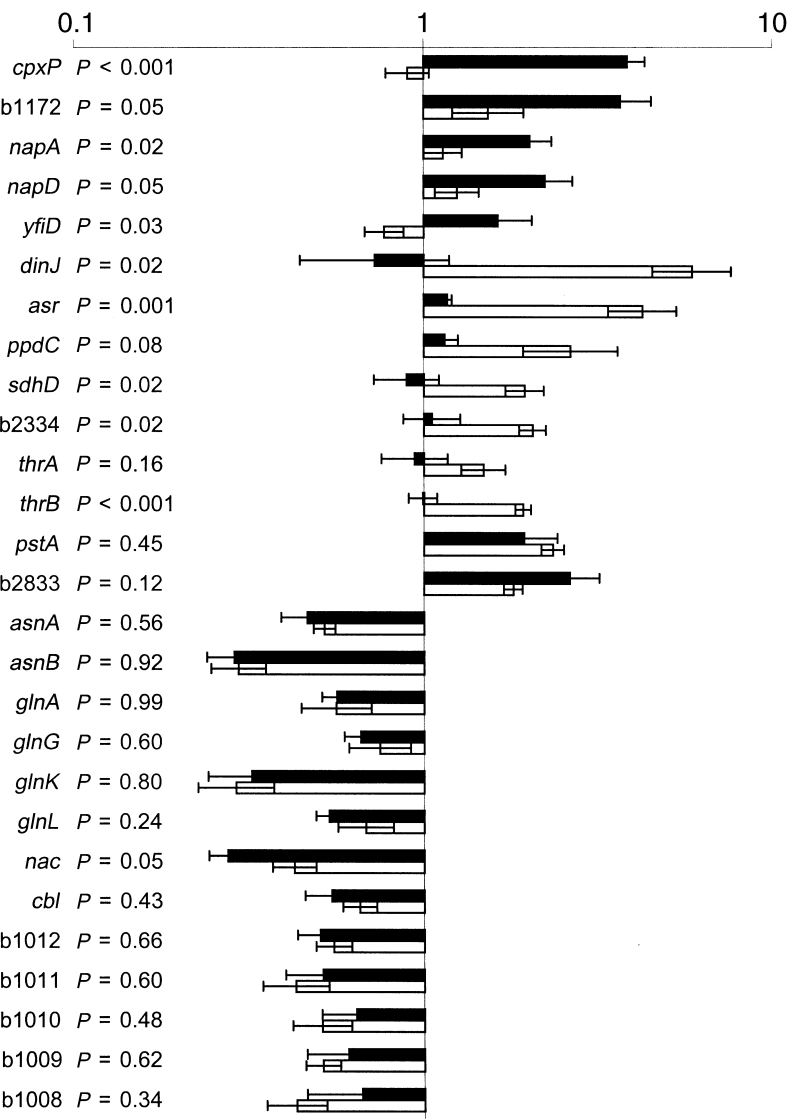

\section{Figure 4}

Common versus unique gene expression changes in non$\mathrm{H}_{2} \mathrm{O}_{2}$-responsive genes induced by phagocyte oxidase-deficient neutrophils. Conditions and symbols are as described in Figure 3. Genes described were selected to highlight significant similarities and differences in the stress effects elicited by normal and phagocyte oxidase-deficient neutrophils. 


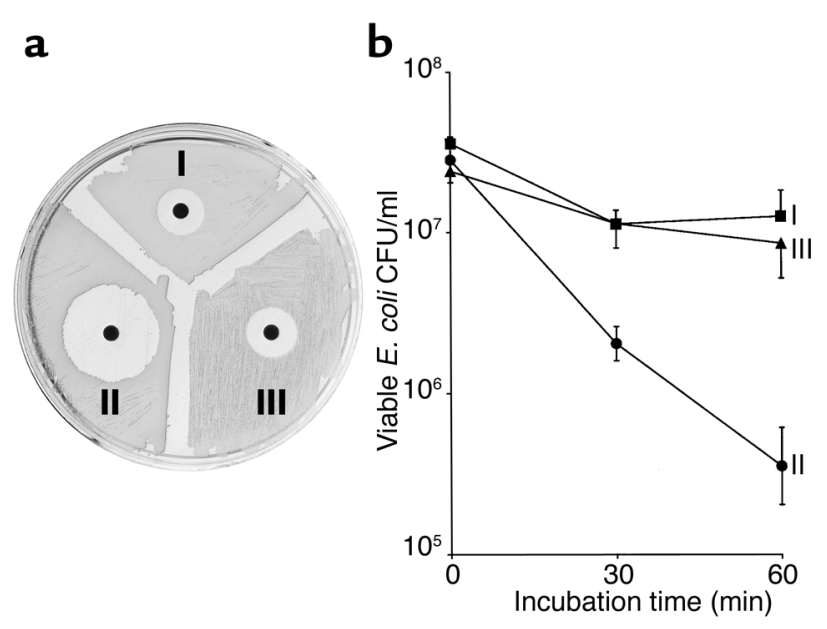

Figure 5

Effects of oxyR gene disruption on bacterial sensitivity to reagent $\mathrm{H}_{2} \mathrm{O}_{2}$ and to neutrophil microbicidal systems. (a) $\mathrm{H}_{2} \mathrm{O}_{2}$ susceptibility of the parent strain (I, ATCC 11775), an oxyRS mutant (II, $\Delta$ oxyRS), and the mutant strain complemented with an oxyR-containing plasmid described in Methods (III, pAQ5). Mueller-Hinton agar was swabbed with a suspension of the appropriate strain, and filter-paper discs were impregnated with $10 \mu \mathrm{l}$ of $1 \mathrm{mM} \mathrm{H}_{2} \mathrm{O}_{2}(10 \mu \mathrm{mol})$ and allowed to grow overnight at $37^{\circ} \mathrm{C}$. Zones of growth inhibition were highly reproducible and stable for days, suggesting a microbicidal effect of the peroxide. (b) Bacterial strains described in a were incubated at a concentration of approximately $30 \times 10^{6}$ bacteria/ml, with $5 \times 10^{6}$ neutrophils $/ \mathrm{ml}$ under conditions otherwise described in Table 2. At indicated times, samples were obtained to determine microbial viability by streaking dilutions of a neutrophil lysate onto Mueller-Hinton agar. Results are shown as the geometric means \pm SE of data from three experiments.

Given the balance between susceptibility and virulence and the large accumulation of genetic and biochemical knowledge of the organism, E. coli seemed ideal to employ in the study of bacteria-neutrophil interactions. The development of a genomic DNA array representative of a laboratory-adapted strain, K12 MG1655, offered the possibility of evaluating transcriptional changes in response to phagocytosis for a large number of bacterial genes in a feasible number of experiments. We expected to infer, from the expression profiles, a bacterial prioritization of the stresses in the phagosome. To compare expression profiles, we sought to define conditions that would emphasize phagosome effects over those engendered by serum exposure, temperature shifts, and nutritional alterations, other than those imposed by sequestration in the phagosome. Temperature and serum effects were allowed to stabilize during a 30 -minute preopsonization phase. Differential complement effects on gene expression proved to be minimal $(t=0$ expression data). The main difference in the comparison conditions was the degree of phagocytosis (Figure 1). As described by others $(23,24)$, heat labile factors in serum, presumably complement components, contributed in a critical way to efficient opsonization and phagocytosis.

Parallel efforts were made to control conditions for RNA isolation. Isolation conditions maintained similar amounts of neutrophils, bacteria, serum proteins, neutrophil nucleases, cell debris, and large contributions of neutrophil DNA. Specificity of bacterial mRNA labeling by reverse transcription in the final complex RNA mixtures (all types of bacterial and eukaryotic RNA) was enhanced by the use of specific primers. The technical advantage of specific primers was improved specificity of transcription, making the method feasible. The limitations were that specific primers would not transcribe genes absent from the K12 genome but present in ATCC 11775, some of which would presumably contribute to virulence.

A nontraditional feature of using DNA arrays to query the bacterial response to phagocytosis is the absence of any hypothesis other than the expectation that changes in gene expression would, in some fashion, be informative. Out of this blank background emerged the observation of a strong induction, following phagocytosis by normal but not CGD neutrophils, of genes coding for proteins that protect against $\mathrm{H}_{2} \mathrm{O}_{2}$. We also detected an increase in the transcription of the superoxide response regulatory gene, soxS. However, an attendant increase in the mRNA levels of downstream genes typically regulated by the soxS transcription factor: $f p r, f u m C, \operatorname{marR} A B, n f o, \operatorname{sod} A$, $z w f$, was not observed. It is likely that the soxS gene was increased in abundance as part of an OxyR-independent $\mathrm{H}_{2} \mathrm{O}_{2}$ stress response (25), not in response to superoxide. The downstream genes were not altered in their expression because the SoxRS response to $\mathrm{H}_{2} \mathrm{O}_{2}$ is significantly weaker than the response to superoxide-generating compounds. Thus, we propose that the phagocytosed bacterium is responding more to $\mathrm{H}_{2} \mathrm{O}_{2}$ than to superoxide.

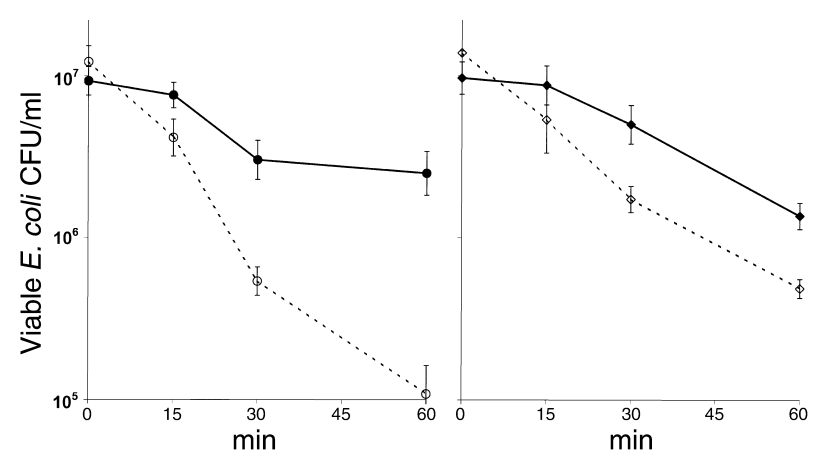

Figure 6

Competitive survival of wild-type and $\triangle$ oxyRS E. coli in normal and oxidase-deficient neutrophils. Bacterial strains employed were wild-type (ATCC 11775 carrying a $\beta$-lactamase plasmid, pBAD18, solid lines and filled symbols) and the $\triangle$ oxyRS mutant described in Figure 5 (dashed lines, open symbols). A mixture of equal numbers of each strain was opsonized and incubated with neutrophils as described in Figure 5. At indicated times, samples were obtained to determine microbial viability by streaking dilutions of a neutrophil lysate onto replicate Mueller-Hinton agar plates containing carbenicillin (100 $\mu \mathrm{g} / \mathrm{ml}$ to select for wild-type survivors) or kanamycin $(10 \mu \mathrm{g} / \mathrm{ml}$ to select for $\Delta$ oxyRS survivors). (a) Normal neutrophils $(n=8)$. (b) Oxidase-deficient neutrophils $(n=4)$. Data points reflect the geometric mean \pm SE of the $n$ independent experiments. 
Another interesting and as yet unexplained result of the expression analysis was the remarkable decrease in expression of genes related to nitrogen metabolism, especially those regulated by the NtrC transcription factor and those associated with $\mathrm{ABC}$ membrane transporters. The majority of these operons are transcribed through the participation of the $\sigma^{54}(\mathrm{rpoN})$ alternative sigma factor and its many obligatory activation factors (33). Based on similar bacterial responses to phagocytosis by normal and oxidase-deficient neutrophils, decreased transcription of these genes seems to be triggered by nonoxidative features of the phagosome environment. The decrease in mRNA transcripts of these genes was unexpected. Sequestration of the microbe in a nutrient-poor phagosome would be expected to elicit a nitrogen starvation response, associated with increased expression of this group of genes. However, most or all of the transcriptional activators of $\sigma^{54}$ are ATPases. The phenomenon of diminished transcription via $\sigma^{54}$ activators may simply reflect severe declines in bacterial ATP levels associated with neutrophil antimicrobial agents. ATP depletion has been demonstrated only for myeloperoxidase-dependent antimicrobial agents, $\mathrm{HOCl}$ and chloramines (45); however, a collapse in the proton motive force associated with membrane-permeabilizing microbicides such as defensins would be expected to have the same effect. Ultimately, a more direct determination of the roles of the $\operatorname{rpoN}\left(\sigma^{54}\right), g \ln G(\mathrm{NtrC})$, and nac genes on microbial survival in neutrophils would be to modulate gene expression and evaluate bacterial susceptibility to neutrophil killing as described next for the OxyR regulon.

An important question bearing on altered gene expression profiles during phagocytosis is whether the changes observed are simply an ineffective "panic" response to a hopeless environment or whether they confer a survival advantage. Because of the straightforward connection between genes of the OxyR regulon and bacterial response to oxidative neutrophil antimicrobial systems, we elected to evaluate bacterial survival in neutrophils after deleting $\operatorname{oxy} R S$. Disruption of the $o x y R$ and $o x y S$ genes increased bacterial susceptibility both to reagent $\mathrm{H}_{2} \mathrm{O}_{2}$, as previously shown (10), and to killing by neutrophils, as described in Figure 5. This defect could be reversed, in each instance, by introduction of a plasmid carrying a functional $o x y R$ gene. The hypersusceptibility to neutrophil killing was more than a log in magnitude (35\% wild-type survival vs. $1 \% \Delta$ oxyRS survival after 60 minutes), suggesting that genes of the OxyR regulon are indeed important for retarding the rate of bacterial killing during neutrophil phagocytosis.

Studies with oxidase-deficient neutrophils indicated that much of the protection afforded by the oxyRS genes defended the bacteria from oxygen-dependent antimicrobial systems of the phagocyte. While ATCC 11775 E. coli bacteria are killed equally well by normal and oxidase-deficient neutrophils (ref. 7; Figure 6), the $\Delta$ oxyRS strain was killed much more effectively by normal neutrophils than by oxidase-deficient neutrophils, supporting an important role for products of the OxyR regulon in defense against oxidative neutrophil antimicrobial systems. Findings described in Figure 6 also suggested a possible but statistically inconclusive role for products of the OxyR regulon in defense against nonoxidative systems, a conjecture that merits further evaluation.

Shortly after the OxyR regulon was identified (46), oxyR mutants of Salmonella typhimurium were challenged with human neutrophils in an assay similar to the one described for E. coli in this report. Contrary to expectation, the $\operatorname{oxy} R^{-}$salmonella were found not to be hypersusceptible to killing (47). However, earlier work examining Salmonella typhi suggested that neutrophil respiratory burst was deficient after ingestion of virulent strains $\left(\mathrm{V}_{\mathrm{i}}^{+}\right)$ of this organism (48). Subsequent studies indicated that a pathogenicity island within the salmonella genome (spi2) encodes for products that suppress the assembly of the neutrophil phagocyte oxidase (49-51). The exclusion of a functional oxidase from the phagosome would diminish the value of antioxidant enzymes in sustaining microbial viability. Our view is that in the absence of a functional phagocyte oxidase - as inherited in CGD and as acquired by ingestion of virulent salmonella - the products of the OxyR regulon are less important to survival in the neutrophil phagosome. By contrast, in the presence of the NADPH oxidase (E. coli ingested by normal neutrophils) the same class of enzymes contributes significantly to tolerance of an oxidizing environment. Thus, it appears that two closely related organisms, E. coli and S. typhimurium, employ different strategies to mitigate the potential harm of neutrophil oxidant stresses.

The identification of the OxyR regulon as a prominent responder to phagocyte-induced stresses led to experiments that were productive in identifying an important defense system for $E$. coli, despite disparate results in a closely related species, S. typhimurium. This unanticipated finding encourages evaluation of the hypothesis that suppression of nitrogen metabolic pathways also enhances survival in some as yet unexplained fashion. Expression profiling can make useful contributions in identifying new avenues to explore for a better understanding of host-pathogen interactions. While the evaluation of expression profiles for genes present in the nonpathogenic K12 strain has borne fruit, it is reasonable to suppose that some of the most interesting virulence genes in pathogens are likely not represented either in laboratory-adapted strains or on the cognate genomic array employed in this study (52). We would wish, in the future, to be able to implement efficient screens designed to identify phagocyte responsive genes of ATCC 11775 not represented in the K12 MG1655 genome, expecting that this also will be a productive area of inquiry.

\section{Acknowledgments}

The authors would like to thank Sydney Kustu (University of California Berkeley), Ferric Fang, Seymour Klebanoff, Colin Manoil (University of Washington), and Gisele Storz (NIH) for reagents and helpful discussions, Roger Bumgarner (University of Washington Microarray Analysis Facility) for access to analytical 
software, and James Johnson (University of Minnesota) for phenotyping strain ATCC 11775. This work was supported, in part, by a grant (AI25606) from the National Institute of Allergy and Infectious Diseases.

1. Kushner, S.R. 1996. mRNA decay. In Escherichia coli and Salmonella typhimurium. Cellular and molecular biology. F.C. Neidhardt, et al., editors. American Society for Microbiology. Washington, D.C., USA. 849-860.

2. Sambrook, J., Fritsch, E.F., and Maniatis, T. 1989. Molecular cloning. A laboratory manual. Cold Spring Harbor Laboratory Press. Cold Spring Harbor, New York, USA.

3. Rosen, H., Michel, B.R., and Chait, A. 1991. Phagocytosis of opsonized oil droplets by neutrophils: adaptation to a microtiter plate format. J. Immunol. Methods. 144:117-125.

4. Dinauer, M.C., Curnutte, J.T., Rosen, H., and Orkin, S.H. 1989. A missense mutation in the neutrophil cytochrome b heavy chain in cytochrome-positive X-linked chronic granulomatous disease. J. Clin. Invest. 84:2012-2016.

5. Hurst, J.K., Loehr, T.M., Curnutte, J.T., and Rosen, H. 1991. Resonance raman and electron paramagnetic resonance structural investigations of neutrophil cytochrome $b_{558}$. J. Biol. Chem. 266:1627-1634.

6. Heyworth, P.G., et al. 1991. Neutrophil NADPH oxidase assembly: translocation of p47-phox and p67-phox requires interaction between $\mathrm{p} 47$-phox and cytochrome $b_{558}$.J. Clin. Invest. 87:352-356.

7. Rosen, H., and Michel, B.R. 1997. Neutrophil-mediated killing of Escherichia coli: redundant contribution of myeloperoxidase-mediated systems. Infect. Immun. 65:4173-4178.

8. Altuvia, S., Almiron, M., Huisman, G., Kolter, R., and Storz, G. 1994. The dps promoter is activated by OxyR during growth and by IHF and sigma $S$ in stationary phase. Mol. Microbiol. 13:265-272.

9. Zheng, M., Doan, B., Schneider, T.D., and Storz, G. 1999. OxyR and SoxRS regulation of fur. J. Bacteriol. 181:4639-4643.

10. Kullik, I., Stevens, J., Toledano, M.B., and Storz, G. 1995. Mutational analysis of the redox-sensitive transcriptional regulator OxyR: regions important for DNA binding and multimerization. J. Bacteriol. 177:1285-1291.

11. Storz, G., Christman, M.F., Sies, H., and Ames, B.N. 1987. Spontaneous mutagenesis and oxidative damage to DNA in Salmonella typhimurium. Proc. Natl. Acad. Sci. USA. 84:8917-8921.

12. Kullik, I., Toledano, M.B., Tartaglia, L.A., and Storz, G. 1995. Mutational analysis of the redox-sensitive transcriptional regulator OxyR: regions important for oxidation and transcriptional activation. J. Bacteriol. 177:1275-1284.

13. Guzman, L.M., Belin, D., Carson, M.J., and Beckwith, J. 1995. Tight regulation, modulation, and high-level expression by vectors containing the arabinose $\mathrm{P}_{\mathrm{BAD}}$ promoter. J. Bacteriol. 177:4121-4130.

14. Merker, R.I., and Troy, F.A. 1990. Biosynthesis of the polysialic acid capsule in Escherichia coli K1. Cold inactivation of sialic acid synthase regulates capsule expression below 20 degrees C. Glycobiology. 1:93-100.

15. Troy, F.A., and McCloskey, M.A. 1979. Role of a membranous sialyltransferase complex in the synthesis of surface polymers containing polysialic acid in Escherichia coli. Temperature-induced alteration in the assembly process. J. Biol. Chem. 254:7377-7387.

16. Whitfield, C., Vimr, E.R., Costerton, J.W., and Troy, F.A. 1984. Protein synthesis is required for in vivo activation of polysialic acid capsule synthesis in Escherichia coli K1. J. Bacteriol. 159:321-328.

17. Richmond, C.S., Glasner, J.D., Mau, R., Jin, H., and Blattner, F.R. 1999. Genome-wide expression profiling in Escherichia coli K-12. Nucleic Acids Res. 27:3821-3835

18. Tao, H., Bausch, C., Richmond, C., Blattner, F.R., and Conway, T. 1999. Functional genomics: expression analysis of Escherichia coli growing on minimal and rich media. J. Bacteriol. 181:6425-6440.

19. Karp, P.D., et al. 2000. The EcoCyc and MetaCyc databases. Nucleic Acids Res 28:56-59.

20. Danese, P.N., and Silhavy, T.J. 1998. CpxP, a stress-combative member of the Cpx regulon. J. Bacteriol. 180:831-839.

21. Prieto-Alamo, M.J., et al. 2000. Transcriptional regulation of glutaredoxin and thioredoxin pathways and related enzymes in response to oxidative stress. J. Biol. Chem. 275:13398-13405.

22. Michan, C., Manchado, M., Dorado, G., and Pueyo, C. 1999. In vivo transcription of the Escherichia coli oxyR regulon as a function of growth phase and in response to oxidative stress. J. Bacteriol. 181:2759-2764.

23. Horwitz, M.A., and Silverstein, S.C. 1980. Influence of the Escherichia coli capsule on complement fixation and on phagocytosis and killing by human phagocytes. J. Clin. Invest. 65:82-94.

24. Leist-Welsh, P., and Bjornson, A.B. 1982. Immunoglobulin-independent utilization of the classical complement pathway in opsonophagocytosis of Escherichia coli by human peripheral leukocytes. J. Immunol. 128:2643-2651.

25. Zheng, M., et al. 2001. DNA microarray-mediated transcriptional profiling of the Escherichia coli response to hydrogen peroxide. J. Bacteriol. 183:4562-4570.
26. Zimmer, D.P., et al. 2000. Nitrogen regulatory protein C-controlled genes of Escherichia coli: scavenging as a defense against nitrogen limitation. Proc. Natl. Acad. Sci. USA. 97:14674-14679.

27. Altuvia, S., Weinstein-Fischer, D., Zhang, A., Postow, L., and Storz, G. 1997. A small, stable RNA induced by oxidative stress: role as a pleiotropic regulator and antimutator. Cell. 90:43-53.

28. Altuvia, S., Zhang, A., Argaman, L., Tiwari, A., and Storz, G. 1998. The Escherichia coli OxyS regulatory RNA represses fhlA translation by blocking ribosome binding. EMBO J. 17:6069-6075.

29. Wassarman, K.M., and Storz, G. 2000. 6S RNA regulates E. coli RNA polymerase activity. Cell. 101:613-623.

30. Zhang, A., Altuvia, S., and Storz, G. 1997. The novel oxyS RNA regulates expression of the sigma s subunit of Escherichia coli RNA polymerase. Nucleic Acids Symp. Ser. 36:27-28.

31. Zhang, A., et al. 1998. The OxyS regulatory RNA represses rpoS translation and binds the Hfq (HF-I) protein. EMBOJ. 17:6061-6068.

32. Schneider, B.L., Kiupakis, A.K., and Reitzer, L.J. 1998. Arginine catabolism and the arginine succinyltransferase pathway in Escherichia coli.J. Bacteriol. 180:4278-4286.

33. Reitzer, L., and Schneider, B.L. 2001. Metabolic context and possible physiological themes of sigma(54)-dependent genes in Escherichia coli. Microbiol. Mol. Biol. Rev. 65:422-444.

34. Blankenhorn, D., Phillips, J., and Slonczewski, J.L. 1999. Acid- and baseinduced proteins during aerobic and anaerobic growth of Escherichia coli revealed by two-dimensional gel electrophoresis. J. Bacteriol. 181:2209-2216.

35. Han, M.J., Yoon, S.S., and Lee, S.Y. 2001. Proteome analysis of metabolically engineered Escherichia coli producing Poly(3-hydroxybutyrate). J. Bacteriol. 183:301-308.

36. Wagner, A.F., et al. 2001. YfiD of Escherichia coli and Y06I of bacteriophage T4 as autonomous glycyl radical cofactors reconstituting the catalytic center of oxygen-fragmented pyruvate formate-lyase. Biochem. Biophys. Res. Comm. 285:456-462.

37. Fernandez, D., et al. 2000. Identification of additional genes belonging to the LexA regulon in Escherichia coli. Mol. Microbiol. 35:1560-1572.

38. Oh, T.J., Lee, C.W., and Kim, I.G. 1999. The damage-inducible (din) genes of Escherichia coli are induced by various genotoxins in a different way. Microbiol. Res. 154:179-183.

39. Diez, A., Gustavsson, N., and Nystrom, T. 2000. The universal stress protein A of Escherichia coli is required for resistance to DNA damaging agents and is regulated by a RecA/FtsK-dependent regulatory pathway. Mol. Microbiol. 36:1494-1503.

40. Suziedeliene, E., Suziedelis, K., Garbenciute, V., and Normark, S. 1999. The acid-inducible asr gene in Escherichia coli: transcriptional control by the phoBR operon. J. Bacteriol. 181:2084-2093.

41. Henderson, L.M., and Meech, R.W. 1999. Evidence that the product of the human X-linked CGD gene, gp91-phox, is a voltage-gated $\mathrm{H}(+)$ pathway. J. Gen. Physiol. 114:771-786.

42. Segal, A.W., Geisow, M., Garcia, R., Harper, A., and Miller, R. 1981. The respiratory burst of phagocytic cells is associated with a rise in vacuolar $\mathrm{pH}$. Nature. 290:406-409.

43. Burg, N.D., and Pillinger, M.H. 2001. The neutrophil: function and regulation in innate and humoral immunity. Clin. Immunol. 99:7-17.

44. Hampton, M.B., Kettle, A.J., and Winterbourn, C.C. 1998. Inside the neutrophil phagosome: oxidants, myeloperoxidase, and bacterial killing. Blood. 92:3007-3017.

45. Barrette, W.C., Jr., Albrich, J.M., and Hurst, J.K. 1987. Hypochlorous acidpromoted loss of metabolic energy in Escherichia coli. Infect. Immun. 55:2518-2525.

46. Storz, G., Tartaglia, L.A., and Ames, B.N. 1990. The OxyR regulon. Antonie Van Leeuwenhoek. 58:157-161.

47. Papp-Szabo, E., Firtel, M., and Josephy, P.D. 1994. Comparison of the sensitivities of Salmonella typhimurium oxyR and kat $G$ mutants to killing by human neutrophils. Infect. Immun. 62:2662-2668.

48. Miller, R.M., Garbus, J., and Hornick, R.B. 1972. Lack of enhanced oxygen consumption by polymorphonuclear leukocytes on phagocytosis of virulent Salmonella typhi. Science. 175:1010-1011.

49. Gallois, A., Klein, J.R., Allen, L.A., Jones, B.D., and Nauseef, W.M. 2001. Salmonella pathogenicity island 2-encoded type III secretion system mediates exclusion of NADPH oxidase assembly from the phagosomal membrane. J. Immunol. 166:5741-5748

50. Vazquez-Torres, A., Fantuzzi, G., Edwards, C.K., Dinarello, C.A., and Fang, F.C. 2001. Defective localization of the NADPH phagocyte oxidase to Salmonella-containing phagosomes in tumor necrosis factor $\mathrm{p} 55$ receptordeficient macrophages. Proc. Natl. Acad. Sci. USA. 98:2561-2565.

51. Vazquez-Torres, A., et al. 2000. Salmonella pathogenicity island 2-dependent evasion of the phagocyte NADPH oxidase. Science. 287:1655-1658.

52. Russo, T.A., Carlino, U.B., and Johnson, J.R. 2001. Identification of a new iron-regulated virulence gene, ire $A$, in an extraintestinal pathogenic isolate of Escherichia coli. Infect. Immun. 69:6209-6216.

53. Prieto-Alamo, M.J., et al. 2000. Transcriptional regulation of glutaredoxin and thioredoxin pathways and related enzymes in response to oxidative stress. J. Biol. Chem. 275:13398-13405. 